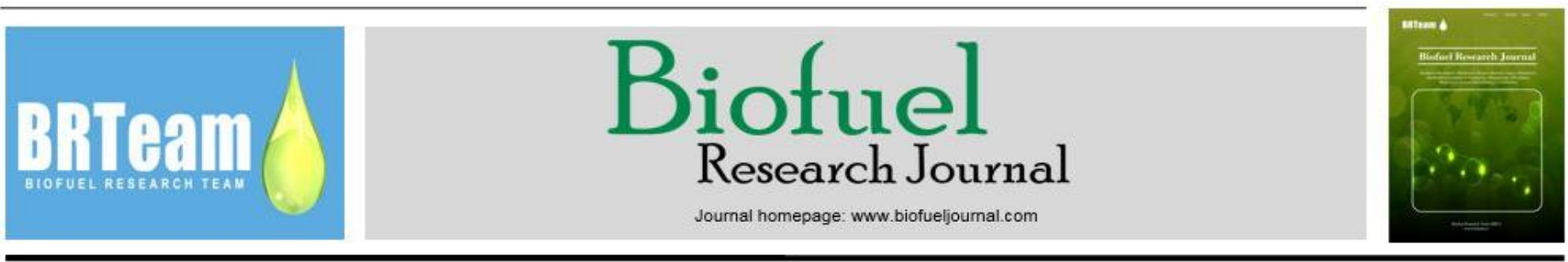

Original Research Paper

\title{
Dry anaerobic digestion of lignocellulosic and protein residues
}

\author{
Maryam M. Kabir*, Mohammad J. Taherzadeh, Ilona Sárvári Horváth
}

Swedish Centre for Resource Recovery, University of Borås, 501 90, Borås, Sweden.

\section{HIGHLIGHTS}

$>$ AD digestion/co-digestion of wool and wheat straw were evaluated with TS contents of between 6 to $30 \%$.

$>$ Methane yield of wheat straw was highest at TS of $21 \%$ and lowest at TS of $30 \%$.

$>$ Methane yield of wool textile was highest at TS of $13 \%$ and lowest at TS of $30 \%$.

$>$ The addition of enzyme on wool and wheat straw led to improvement in methane yield at TS of $13 \%$. $>$ Synergetic effects were observed when these substrates were co-digested.

\section{ARTICLE INFO}

\section{Article history:}

Received 7 September 2015

Received in revised form 29 September 2015

Accepted 30 September 2015

Available online 1 December 2015

\section{Keywords:}

Dry anerobic digestion

Lignocellulosic biomass

Wheat straw

Wool

Keratin

Enzyme addition

\section{GRAPHICAL ABSTRACT}

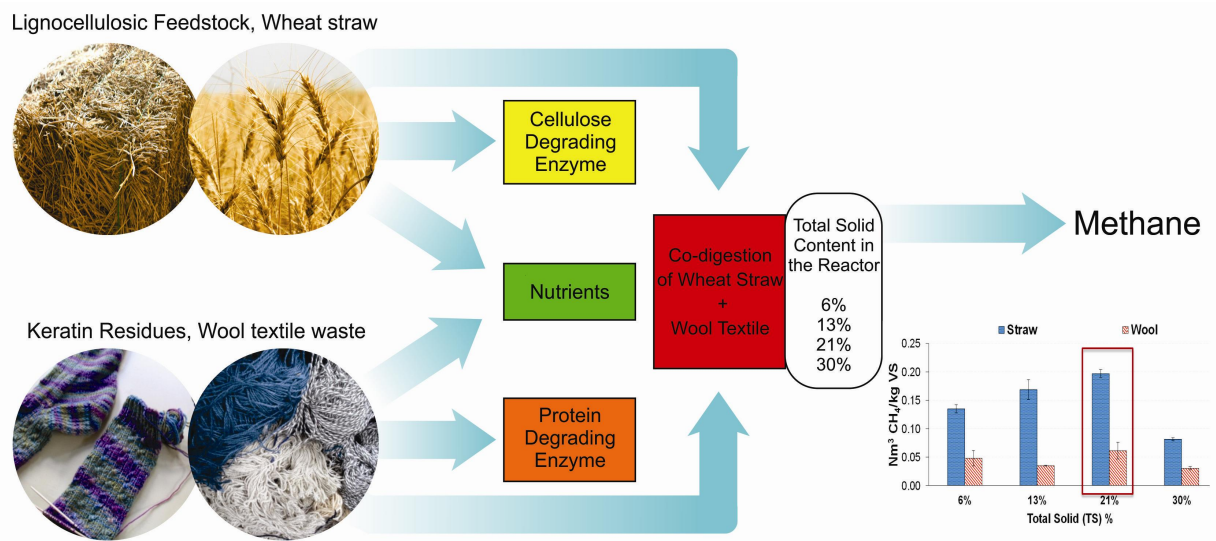

(C) 2015 BRTeam. All rights reserved.

* Corresponding author at: Tel.: +46-334354855

E-mail address: maryam.kabir@hb.se

Please cite this article as: Kabir M.M., Taherzadeh M.J., Sárvári Horváth I. Dry anaerobic digestion of lignocellulosic and protein residues. Biofuel Research Journal 8 (2015) 309-316. DOI: 10.18331/BRJ2015.2.4.5 


\section{Introduction}

Anaerobic digestion (AD) has received tremendous attention recently as a consequence of a growing demand for renewable energies together with increasingly-stringent environmental regulations. This technology has been used in processing of municipal and industrial sludge for almost 100 years (Chandler and Jewell, 1980). The product of the AD, the biogas, is a versatile energy source, which can be utilised for the generation of heat and/or electricity, either separated or combined and in addition, it can be upgraded and used as vehicle fuel (Ghosh et al., 2000; Shafiei et al., 2011; Salehian et al., 2013). The $\mathrm{AD}$ process is classified as wet- $\mathrm{AD}$ and solid-state/dry-AD, based on the total solids (TS) content of the feedstock in the digester. Generally, TS content in wet-AD digesters is lower than $10 \%$, whereas in dry fermentation, it is higher than 10\% (De Baere and Mattheeuws, 2008; Zhu et al., 2010). During the past few years, over 63\% of the new AD plant installations in Europe were based on dry- $\mathrm{AD}$ (De Baere and Mattheeuws, 2008; Kiran et al., 2014).

The increasing interest in dry- $\mathrm{AD}$ based plants can generally be explained by the advantages of the dry-AD processes over the wet- $\mathrm{AD}$ processes. More specifically, due to the increase in TS content in the dry-AD, this process requires a smaller reactor volume, which consequently reduces the material cost and the energy required for heating. Moreover, the digestate can easily be subjected to composting and then used as soil conditioner or fertilizer as no or minimal dewatering is needed. Furthermore, problems related to the wet-AD, such as floating of scum layer can be avoided (Chanakya et al., 1993; Nordberg and Edström, 1997).

Lignocellulosic biomass and textile wastes could be ideal substrates for dry-AD, due to their high abundance and their low moisture content. The global production of fibres has shown a constant increase in the past few decades (Akia et al., 2014; Barchyn and Cenkowski, 2014; Pothiraj et al., 2015). According to the Food and Agriculture Organization of the United Nations (FAO), the annual wool production is estimated at approximately 2.1 million tonnes per year (International Wool Textile Organization: IWTO, 2015). These fibres, after recycling and reuse for textile and other applications, would finally end up in waste stations. Consequently, the disposal of this large volume of fibre wastes has evolved into a major concern for the textile industry today.

Wool is mainly composed of a recalcitrant protein, keratin, $(\approx 97 \%)$ and lipids $(\approx 1 \%)$ (Heine and Höcker, 1995). Due to its high protein content, it can be used as an alternative renewable biomass source for the production of value-added products, via chemical, physicochemical, and microbial processes. One novel approach is the application of biological degradation of wool-based textiles for biogas production.

On the other hand, among the large amounts of different lignocellulosic biomass produced within the EU, straw generation is projected to be approximately 127 million tonnes in the year 2020 . This is equal to 49.3 Mtoe (million tonnes oil equivalent) (Kretschmer et al., 2012). This high potential as well as the availability of straw and its high carbon content make it a promising substrate for biofuel production.

Hence, the main aim of this study was to explore the performance of AD of wheat straw and wool textile waste alone as well as in co-digestion using wet, semi dry, and dry-AD processes. The TS contents were therefore varied between $6-30 \%$ during the investigations. The effect of the addition of cellulose- or protein-degrading enzymes, as well as the effect of the addition of nutrients on the performance of the $\mathrm{AD}$ processes was also determined. Furthermore, chemical compositions and structural variations of these substrates during the degradation process were also investigated. To the best of our knowledge, this is the first report on the dry-digestion process of wheat straw and wool textile waste as co-substrates.

\section{Materials and methods}

\subsection{Preparation of wool and wheat straw substrates}

Wool textile waste, consisting of 70\% wool (protein) and 30\% polyamide, was obtained from the Woolpower AB (Östersund, Sweden). This textile waste was then ground to particles approximately $2 \mathrm{~mm}$ in size using a Retsch $\mathrm{GmbH}$ SM 100 comfort miller (Germany) and stored until further investigation. Wheat straw used in this study was supplied by Lantmännen Agroetanol (Norrköping, Sweden). The composition of the wheat straw was determined based on the dry matter of the wheat straw: $35 \%$ cellulose, $22 \%$ hemicellulose, $18 \%$ insoluble lignin, and $16 \%$ extractives. The straw was milled into particles of between 2 to $5 \mathrm{~mm}$ in size, using a Octagon 200 sieve shaker (UK) and stored prior to analyses and anaerobic digestion.

\subsection{Anaerobic digestion assays}

The methane potential of different substrate combinations under different conditions were determined using batch anaerobic digestion assays. The milled wheat straw or wool textile waste as well as a mixture of these two were mixed with a predetermined amount of inoculum and deionized water to achieve a substrate to inoculum ratio (S/I) of 2:1 (based on the volatile solids -VS- content) (Liew et al., 2012), and an initial TS contents of $6 \%, 13 \%, 21 \%$ and $30 \%$. The inoculum was obtained from a farm-scale digester located at Vårgårda-Herrljunga Biogas $\mathrm{AB}$ (Sweden), operating at mesophilic temperature $\left(37^{\circ} \mathrm{C}\right)$. Because of the low TS content, the inoculum was centrifuged and the supernatant was discharged to achieve the desirable TS for the dry-AD The remaining sludge was mixed to obtain a homogenous inoculum. The $\mathrm{AD}$ of the wheat straw or wool textile waste was investigated even with the addition of enzymes, Cellic ${ }^{\circledR}$ CTec 3 enzyme (Novozomes, Denmark) or an alkaline endopeptidase (Savinase ${ }^{\circledR} 16$ L, Type EX), respectively. The cellulolytic enzyme load was 10 FPU (Filter Paper Unit)/g straw and the endopeptidase load was $10 \mathrm{KNPU}$ (Kilo Novo Protease Unit)/g textile. These enzymes were added to the digesters directly when starting up the AD process.

Furthermore, wool or straw was also digested with the addition of nutrients. The final nutrient concentrations for the basal medium $(1 \mathrm{~g} / \mathrm{L}$ substrate, containing inorganic macronutrients) were $(\mathrm{mg} / \mathrm{L}): \mathrm{NH}_{4} \mathrm{Cl}$ (76.4), $\mathrm{KH}_{2} \mathrm{PO}_{4}(5.18), \mathrm{MgSO}_{4} \cdot 7 \mathrm{H}_{2} \mathrm{O}(0.27), \mathrm{CaCl}_{2} \cdot 2 \mathrm{H}_{2} \mathrm{O}$, (10.00), and trace nutrients, $1 \mathrm{ml} / \mathrm{L}$ (Osuna et al., 2003). Finally, the co-digestion of the wheat straw and wool textile waste (ratio 1:1 based on the VS content) was investigated using similar TS concentrations as in the mono-digestion assays.

After the set-ups were prepared, anaerobic conditions were obtained by purging the reactors with nitrogen gas for about $2 \mathrm{~min}$, and the reactors were then incubated in a convection oven under mesophilic conditions (37 $\pm 1^{\circ} \mathrm{C}$ ). Inoculum without adding any substrate was also evaluated as blank to determine the methane production of the inoculum itself. The accumulated methane production was measured by taking gas samples regularly from the headspace during a 50-d long examination period.

\subsection{Analytical methods}

The TS and VS of the investigated substrates were determined according to Sluiter et al. (2008a). Total nitrogen content of the wool textile waste before and after digestion was determined by Kjeldahl digestion, using a 2020 Kjeltec Digestor and a 2400 Kjeltec Analyser unit (FOSS analytical A/S Hilleröd, Denmark). The extractive content of the wheat straw was measured according to Sluiter et al. (2005). Furthermore, the structural carbohydrates content was determined using a two-step hydrolysis method described by Sluiter et al. (2008b). The sugars were quantified by high performance liquid chromatography (HPLC) (Waters 2695, Millipore and Milford, USA) equipped with a refractive index (RI) detector (Waters 2414, Millipore and Milford, USA), using a Pb-based ion exchange column (Aminex HPX-87P, Bio-Rad, USA). The eluent was pure water with a flow rate of $0.6 \mathrm{~mL} / \mathrm{min}$ at $85^{\circ} \mathrm{C}$.

Fourier transform infrared spectroscopy (FTIR) (Impact 410, Nicolet Instrument Corp., Madison, WI) was used to measure the cellulosic crystallinity. The spectra were achieved with an average of 64 scans and a resolution of $4 \mathrm{~cm}^{-1}$ in the range from 600 to $4000 \mathrm{~cm}^{-1}$ and controlled by the Nicolet OMNIC 4.1 analysing software. The crystallinity was analysed by considering the absorbance bands at 1422 and $898 \mathrm{~cm}^{-1}$, assigned to cellulose I and cellulose II (amorphous cellulose), respectively (Carrillo et al., 2004). The absorbance ratio of $\mathrm{A}_{1422} / \mathrm{A}_{898}$ was used to measure the crystallinity index of the wheat straw before and after digestion, and that of the digested straw in the presence of the enzyme.

The protein secondary structure in the wool textile waste was also investigated by FTIR spectrometery. The most sensitive spectral region to 
the protein secondary structural components is the amide I band, which appears in the absorption bands of $1700-1600 \mathrm{~cm}^{-1}$ due to the $\mathrm{C}=\mathrm{O}$ stretch vibrations of the peptide linkage. To analyse the amide I band component, the second derivative spectra was curve fitted and used to identify the composite absorptions attributed to $\alpha$-Helix, $\beta$-Sheet and disordered microstructural components, respectively, before and after 50 days of anaerobic digestion (Kong and Yu, 2007). The percentage of the $\alpha$-Helix, $\beta$-Sheet and disordered microstructures were determined by adding the sum of absorptions for each and stating their sums as a fraction of total amide I band area (Cardamone, 2010).

Methane production was measured using a gas chromatograph (GC) (Auto System, Perkin Elmer, USA) equipped with a packed column (Perkin Elmer, 6 ' x 1.8" OD, 80/100, Mesh, USA) and a thermal conductivity detector (Perkin Elmer) with an inject temperature of $150^{\circ} \mathrm{C}$. Nitrogen was used as carrier gas at $75^{\circ} \mathrm{C}$ with a flow rate of $20 \mathrm{~mL} / \mathrm{min}$. A $250 \mu \mathrm{L}$ pressure-tight syringe (VICI, Precision Sampling Inc., USA) was used for gas sampling. To avoid overpressure built up in the digesters, the excess gas was released through a needle after each gas sampling. The results were presented as $\mathrm{Nm}^{3}$ $\mathrm{CH}_{4} / \mathrm{kg}$ VS and were calculated as the volume of methane gas produced per $\mathrm{kg}$ of VS loaded into each reactor at the start-up and were corrected by subtracting the methane volume obtained from the blank reactor containing the inoculum only. The volumetric productivity of methane expressed as $\mathrm{V}_{\text {methane }} / \mathrm{V}_{\text {working volume}}$, meaning the $\mathrm{m}^{3}$ of methane gas produced $\left(\mathrm{V}_{\text {methane }}\right)$ per $\mathrm{m}^{3}$ of working volume of the reactor $\left(\mathrm{V}_{\text {working volume }}\right)$, was also determined.

\subsection{Statistical analyses}

All AD assays as well as the compositional and structural analyses were run in triplicates. Statistical analysis was performed using the software package MINITAB ${ }^{\circledR}$. All error bars and intervals reported represent one standard deviation. ANOVA general linear model was applied to evaluate the methane production and the effect of the varying TS content in the digesters with a significance threshold (p-value) of 0.05 . The effects of the addition of nutrients and enzymes on the anaerobic digestion process were evaluated via two sample comparative t-test using the MINITAB ${ }^{\circledR}$.

\section{Results and discussion}

\subsection{Anaerobic digestion of wheat straw and wool textile waste}

The $\mathrm{AD}$ of wheat straw and wool textile waste was investigated using four different TS contents (i.e., 6, 13, 21 and 30\%) in batch operation mode. The accumulated methane production was determined during a 50$\mathrm{d}$ long digestion period. The S/I ratio (based on the VS content) was set to 2 in each digester, while the TS concentrations varied between $6-30 \%$ The obtained accumulated methane yields and volumetric productivities are presented in Figure 1 and Table 1.

\subsubsection{Anaerobic digestion of wheat straw}

In the $\mathrm{AD}$ of wheat straw (without addition of enzyme and nutrients), the methane yields obtained were between $0.081-0.200 \mathrm{Nm}^{3} \mathrm{CH}_{4} / \mathrm{kg}$ VS (Table 1 and Fig.1). The highest methane yields were determined when the TS concentrations of 13 and $21 \%$ were used, with methane productions of 0.170 and $0.200 \mathrm{Nm}^{3} \mathrm{CH}_{4} / \mathrm{kg} \mathrm{VS}$, respectively. To the contrary, the methane production rate was significantly reduced when the straw was digested using the TS contents of $6 \%\left(0.135 \mathrm{Nm}^{3} \mathrm{CH}_{4} / \mathrm{kg} \mathrm{VS}\right)$ or $30 \%\left(0.081 \mathrm{Nm}^{3} \mathrm{CH}_{4} / \mathrm{kg}\right.$ VS). However, according to the statistical analyses, the methane production rate of the dry-AD using the TS contents of 13 or $21 \%$ did not differ significantly $(p>0.05)$.

Table 1.

Accumulated methane production ( $\mathrm{Nm} 3 \mathrm{CH} 4 / \mathrm{kg}$ VS), methane volumetric productivity ( $\mathrm{Nm} 3 / \mathrm{m} 3$ Working Volume), and the expected calculated methane yield from the co-digested mixture, at TS contents of $6 \%, 13 \%, 21 \%$, and $30 \%$.

\begin{tabular}{|c|c|c|c|c|}
\hline & Feedstock & $\begin{array}{l}\text { Accumulated methane yield } \\
\qquad\left(\mathrm{Nm}^{3} \mathrm{CH}_{4} / \mathrm{kg} \mathrm{VS}\right)\end{array}$ & $\begin{array}{c}\text { Volumetric productivity } \\
\text { ( } \mathrm{m}^{3} \mathrm{CH} 4 / \mathrm{m}^{3} \text { Working Volume) }\end{array}$ & $\begin{array}{l}\text { Expected methane yields of co-digested } \\
\text { mixture }\left(\mathrm{Nm}^{3} \mathrm{CH}_{4} / \mathrm{kg} \mathrm{VS}\right)\end{array}$ \\
\hline \multirow{8}{*}{$\overbrace{0}^{\circ}$} & Straw & $0.135 \pm 0.007$ & 0.011 & - \\
\hline & Straw+ Enzyme & $0.171 \pm 0.030$ & 0.014 & - \\
\hline & Straw+ Nutrient & $0.141 \pm 0.013$ & 0.012 & - \\
\hline & Wool & $0.048 \pm 0.013$ & 0.004 & - \\
\hline & Wool+ Enzyme & $0.108 \pm 0.005$ & 0.009 & - \\
\hline & Wool+ Nutrient & $0.058 \pm 0.009$ & 0.005 & - \\
\hline & Wool+ Straw & $0.136 \pm 0.009$ & 0.014 & 0.091 \\
\hline & Wool+ straw + nutrient & $0.143 \pm 0.011$ & 0.012 & 0.102 \\
\hline \multirow{8}{*}{$\begin{array}{l}\stackrel{2}{2} \\
\stackrel{\circ}{2}\end{array}$} & Straw & $0.170 \pm 0.017$ & 0.021 & - \\
\hline & Straw+ Enzyme & $0.231 \pm 0.011$ & 0.029 & - \\
\hline & Straw+ Nutrient & $0.204 \pm 0.006$ & 0.025 & - \\
\hline & Wool & $0.035 \pm 0.000$ & 0.005 & - \\
\hline & Wool+ Enzyme & $0.131 \pm 0.005$ & 0.016 & - \\
\hline & Wool+ Nutrient & $0.088 \pm 0.002$ & 0.011 & - \\
\hline & Wool+ Straw & $0.100 \pm 0.010$ & 0.012 & 0.102 \\
\hline & Wool+ straw + nutrient & $0.133 \pm 0.003$ & 0.016 & 0.146 \\
\hline \multirow{8}{*}{$\frac{n}{2}$} & Straw & $0.200 \pm 0.007$ & 0.033 & - \\
\hline & Straw+ Enzyme & $0.211 \pm 0.002$ & 0.035 & - \\
\hline & Straw+ Nutrient & $0.225 \pm 0.013$ & 0.037 & - \\
\hline & Wool & $0.061 \pm 0.014$ & 0.010 & - \\
\hline & Wool+ Enzyme & $0.040 \pm 0.007$ & 0.000 & - \\
\hline & Wool+ Nutrient & $0.089 \pm 0.009$ & 0.015 & - \\
\hline & Wool+ Straw & $0.154 \pm 0.001$ & 0.026 & 0.130 \\
\hline & Wool+ straw + nutrient & $0.177 \pm 0.021$ & 0.030 & 0.157 \\
\hline \multirow{8}{*}{$\begin{array}{l}\text { की } \\
\stackrel{\circ}{\circ}\end{array}$} & Straw & $0.081 \pm 0.002$ & 0.016 & - \\
\hline & Straw+ Enzyme & $0.052 \pm 0.002$ & 0.010 & - \\
\hline & Straw+ Nutrient & $0.070 \pm 0.000$ & 0.014 & - \\
\hline & Wool & $0.030 \pm 0.002$ & 0.006 & - \\
\hline & Wool+ Enzyme & $0.033 \pm 0.003$ & 0.006 & - \\
\hline & Wool+ Nutrient & $0.013 \pm 0.008$ & 0.003 & - \\
\hline & Wool+ Straw & $0.090 \pm 0.005$ & 0.020 & 0.055 \\
\hline & Wool+ straw + nutrient & $0.097 \pm 0.006$ & 0.020 & 0.041 \\
\hline
\end{tabular}



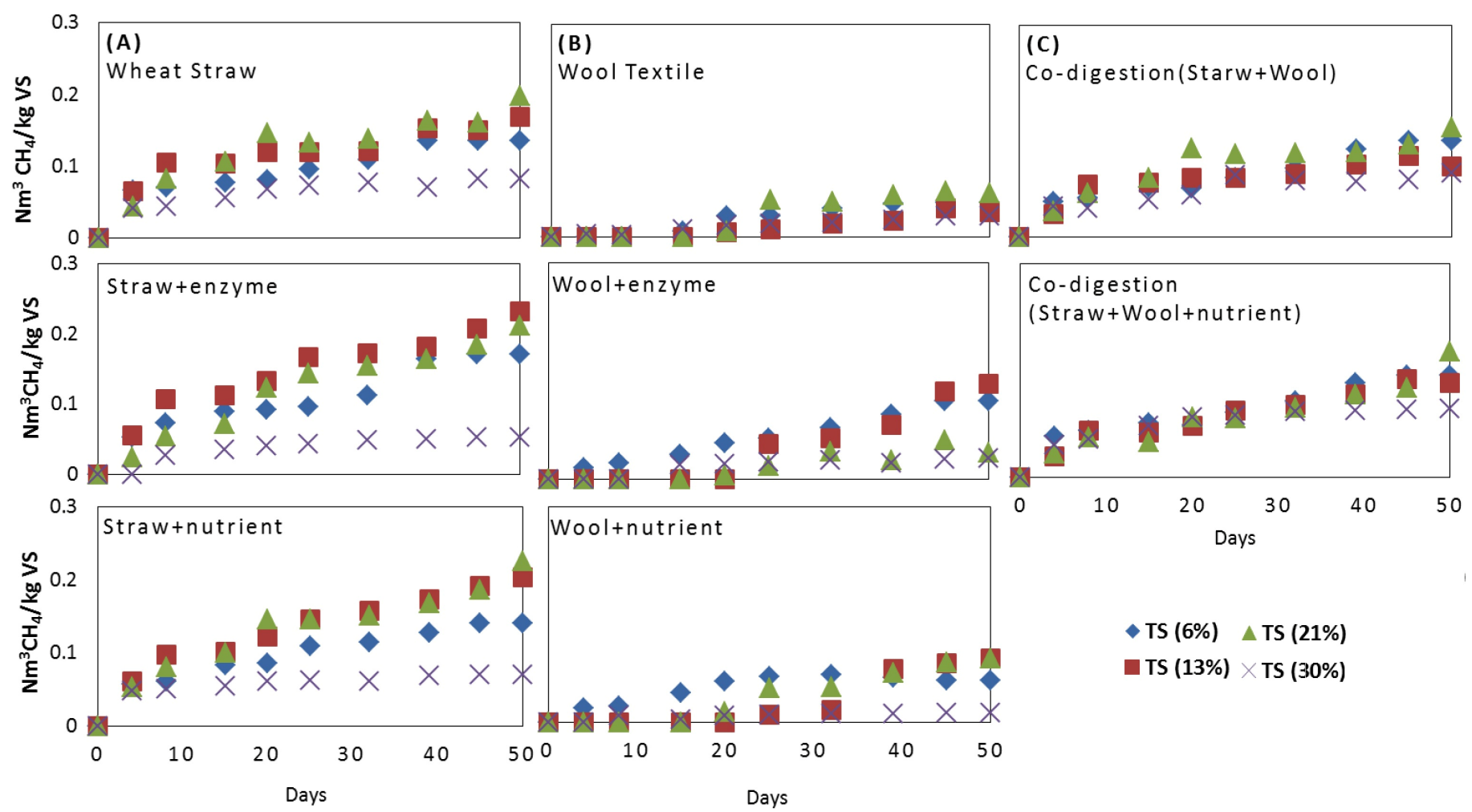

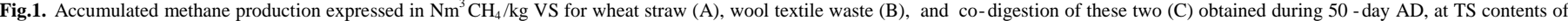
$6 \%, 13 \% 21 \%$ and $30 \%$. The digestion conditions are described in the figure.

The effect of the addition of nutrients in the AD of wheat straw was also examined, and the obtained methane yields were $0.141,0.204,0.225$ and $0.070 \mathrm{Nm}^{3} \mathrm{CH}_{4} / \mathrm{kg}$ VS, in reactors containing 6, 13, 21 and $30 \% \mathrm{TS}$, respectively. The statistical analyses of the results showed that there was no significant difference between the methane yields obtained without and with the nutrients addition.

The enzymes that are responsible for degradation of biomass in the $\mathrm{AD}$ system are intrinsically present in digesters as they are excreted by the microorganisms. However, to improve the breakdown process, excess enzyme loading was applied in the present study. The enzymes used were directly added to the vessels at the start-up of the digestion process. AD of the wheat straw supplied with excess cellulolytic enzyme resulted in methane yields of $0.171,0.213,0.211$ and $0.052 \mathrm{Nm}^{3} \mathrm{CH}_{4} / \mathrm{kg} \mathrm{VS}$, for TS contents of $6,13,21$ and $30 \%$, respectively.

By comparing the methane potential reported previously for wheat straw and what obtained in batch wise wet-AD studies (ranging between 0.189 $0.200 \mathrm{Nm}^{3} \mathrm{CH}_{4} / \mathrm{kg}$ VS) at mesophilic conditions (Jurado et al., 2013) with the results of the current work, it can be concluded that almost similar methane yields $\left(0.170-0.200 \mathrm{Nm}^{3} \mathrm{CH}_{4} / \mathrm{kg}\right.$ VS) were achieved even in the dry digestion mode, with the advantage of more organic loading in the system. Moreover, the simultaneous addition of cellulose- degrading enzymes at the start up of the digestion process could significantly enhance the methane production at the TS content of $13 \%$, leading to $0.231 \mathrm{Nm}^{3} \mathrm{CH}_{4} / \mathrm{kg}$ VS methane production. However, the statistical analyses showed that the addition of enzyme caused no significant differences $(p>0.05)$ at all the other TS contents applied. A possible explanation for that might be the presence of a lignin shield surrounding the cellulose fraction of the straw, which ultimately hindered the enzyme accessibility to the substrate. As reported earlier (Karimi et al., 2013), the binding of lignin to the cellulase enzymes is irreversible, and it can lead to the deactivation of the enzymes, thus reducing their effectiveness.

The volumetric methane productivity (shown in Table 1) was also evaluated. The determination of the volumetric methane productivity is an important factor when considering the economy of $\mathrm{AD}$ processes. The volumetric productivities determined during this study showed that the highest methane production from straw could be achieved using the TS contents of $13 \%$ (i.e., $0.021-0.030 \mathrm{~m}^{3} \mathrm{CH}_{4} / \mathrm{m}^{3}$ working volume) or $21 \%$, (i.e., $0.033-0.037 \mathrm{~m}^{3} \mathrm{CH}_{4} / \mathrm{m}^{3}$ working volume), respectively (Table 1 ).

Generally, the higher methane yields obtained at the TS contents of 13 and $21 \%$ might be related to the nature of the straw, which can act as a structural biofilm carrier. In $\mathrm{AD}$ systems, when biofilm carriers are present in the reactor, syntrophic interactions between a large variety of microorganisms can occur, which could subsequently lead to higher methane yields. This is in agreement with the findings obtained in previous studies where additional biofilm carriers were applied using inert or naturally-degradable materials, like straw, to which the microbial population could be attached (Kazda et al., 2012; Ward et al., 2008). Due to the cell's natural tendency to form dense granules, additional biofilm carriers would enhance process stability, which will lead to increased methane yields (Ward et al., 2008). Previously, Andersson and Björnsson (2002) also found that the addition of straw in a two-stage anaerobic digestion system resulted in an improvement in the digestion performance with enhanced methane production.

Therefore, one can expect that the AD of straw in a dry system would lead to increased cell tendencies for attachment to the surface of the straw making the degradation more efficient. This could also be easily comprehended from the results of this study, revealing high gas production per unit volume in digesters operating at 2 or 3 times higher TS contents of straw, compared with wet AD systems. During these conditions, highly-efficient degraders can be developed and/or retained in the system due to an increased accessible surface area. Hence, the cost effectiveness of the dry-AD process increases (Jewell et al., 1993). On the other hand, the biomethane potential of straw in reactors with the highest TS concentration of $30 \%$ was not high in this study. This can be the consequence of excessive shortage of moisture in the reactor, which finally deteriorates the digestion process. This result is in accordance with 
those of the previous studies reporting a dramatic decrease in biogas production with TS contents ranging between 30 to 50\% (Jewell et al., 1993). Moreover, according to Wujcik and Jewell (1980), high TS contents of 30 to $40 \%$ cause inhibition of the $\mathrm{AD}$ due to the accumulation of volatile fatty acids (VFAs).

\subsubsection{Anaerobic digestion of wool textile waste}

The AD of wool textile waste was investigated as well at similar TS concentrations (i.e., $6-30 \%$ ). Furthermore, the effect of simultaneous addition of a protein-degrading enzyme and the addition of nutrients were also taken into account. The results obtained are summarised in Figure 1 and Table 1.

The methane yields obtained without the addition of enzyme and nutrients were low, ranging between 0.030 to $0.061 \mathrm{Nm}^{3} \mathrm{CH}_{4} / \mathrm{kg}$ VS at the TS contents of $6-30 \%$ (Fig. 1). Interestingly, no significant differences in methane yields were observed as the TS increased from 6 to $30 \%$ ( $p>0.05$ ). Similarly, the addition of nutrients did not cause a significant improvement in the $\mathrm{AD}$ of the wool textile waste. However, the addition of the protein-degrading enzyme could significantly enhance the methane production at the TS contents of 6 and $13 \%$, resulting in 0.108 and $0.131 \mathrm{Nm}^{3} \mathrm{CH}_{4} / \mathrm{kg}$ VS, respectively. Previously, in a wet-AD system and at thermophilic conditions, only $5 \%$ of the expected theoretical yield from the protein fraction of similar textile waste could be achieved (i.e., $0.020 \mathrm{~m}^{3} \mathrm{CH}_{4} / \mathrm{kg}$ VS) (Kabir et al., 2013). While in the present study, the degradation of wool textile waste in the dry-AD mode resulted in 3 and 6.5 times higher methane yields, without and with the addition of a protein-degrading enzyme, respectively.

The highest protein conversion of the wool textile waste into biomethane was obtained using the enzyme supplement at the TS content of $13 \%(0.131$ $\mathrm{m}^{3} \mathrm{CH}_{4} / \mathrm{kg} \mathrm{VS}$ ), corresponding to $38 \%$ of the expected theoretical yield from this substrate. However, a descending trend in the methane yield was observed when enzyme addition was conducted at the TS contents of $21 \%$ and 30\% (of 0.040 and $0.032 \mathrm{~m}^{3} \mathrm{CH}_{4} / \mathrm{kg} \mathrm{VS}$, respectively). The reason for this low gas production at higher TS concentrations might be the increase in the mass transfer barrier for the diffusion of VFAs (Bollon et al., 2013), which leads to the accumulation of VFAs in the system. Besides, as the addition of enzyme accelerates the degradation rate of proteins (Forgács et al., 2013), the consequent accumulation of ammonium nitrogen might be another reason behind the low methane yield (Forgács et al., 2013).

Furthermore, there was a 20-d long lag period observed in the digestion of the wool textile waste, at all TS concentrations investigated (Fig. 1). Nevertheless, the process was initiated, and the methane production started up in the reactors containing $6-21 \%$ TS while the digestion failed when the TS concentration was increased to $30 \%$. These results are in accordance with those obtained previously by Forgács et al. (2013) who used chicken feather ( $\beta$-keratin protein) as feedstock in a semi-continuous anaerobic co-digestion process. In their study, after an initial period of $20 \mathrm{~d}$, the ammonium-nitrogen concentration increased to $4,200 \mathrm{mg} / \mathrm{L}$ in the reactors where enzyme was added together with feather, resulting in a decrease in the methane production. However, the system became stabilised afterwards together with a slow decrease in ammonium-nitrogen concentration.

Table 1 presents the volumetric methane productivity determined when the wool textile waste was digested at different TS levels. The results obtained showed that the volumetric productivity was highest when the TS content of $13 \%$ was used. However, the volumetric productivity decreased when the TS was further increased to 21 and $30 \%$.

\subsubsection{Co-digestion of wheat straw and wool textile}

The co-digestion of wool textile wastes and wheat straw (in a ratio of 1:1 based on the VS) was also investigated using similar TS contents with or without the addition of nutrients. The expected methane yields for the codigested mixture can be calculated from the methane potentials obtained for the individual fractions (Table 1). All the co-digestion assays showed higher accumulated methane yields than the calculated expected levels, with an exception of when the TS content of $13 \%$ was used. According to Alvarez and Lidén (2008) and Pagés Díaz et al. (2011), the accumulated methane yield in a co-digestion process can be higher than the calculated expected value, due to the synergic effects developed in the digester. Interestingly, the methane production of the co-digested wheat straw and wool textile waste was the highest, showing an increase of 58\%, compared with the expected value, when the TS content of $30 \%$ together with addition of nutrients was applied. Furthermore, similar TS content without nutrients supplementation led to an increase of $39 \%$, compared with the expected methane yield. Since, higher TS concentrations or higher S/I ratio generally results in a slowdown in the microbial growth (Batstone et al., 2002; Yang and Li, 2014), it is expected that digesters containing 30\% TS, more likely suffer from nutritional imbalances, compared with digesters running on lower TS contents. Therefore, co-digestion of the carbon-rich straw with the nitrogen-rich wool textile waste provided a nutrient efficient feedstock with a more balanced $\mathrm{C} / \mathrm{N}$ ratio even at the TS content of $30 \%$; and this consequently resulted in a noticeable improvement in methane production.

Furthermore, this improvement was even higher when additional nutrients were added to the digestion system. The results of this study are in agreement with those of the study conducted by Kayhanian and Rich (1995), which suggested that mixing of two or three organic wastes could provide a nutrient-sufficient feedstock for a dry-AD process.
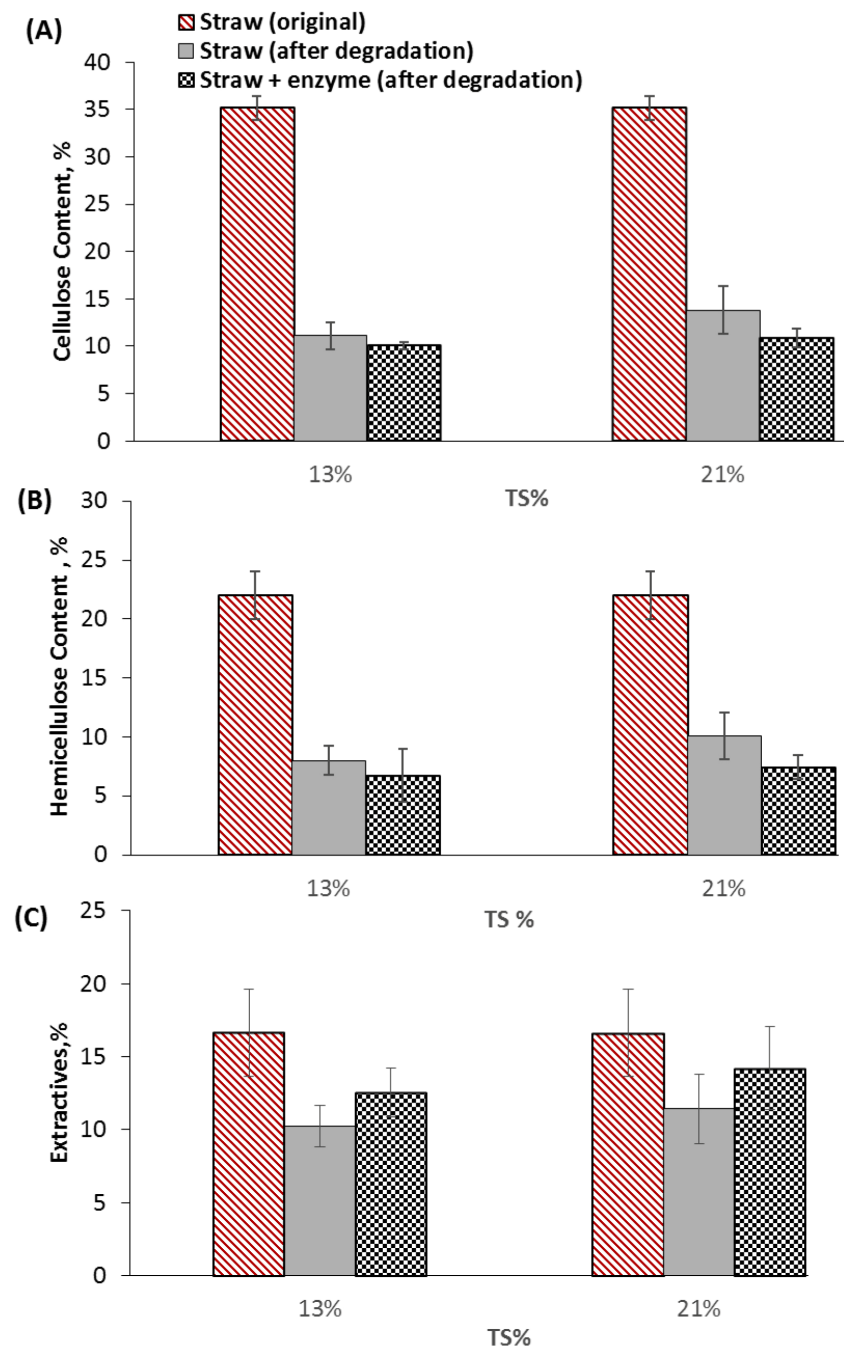

Fig.2. Degradation of cellulose \% (A), hemicellulose \% (B), and extractives \% (C) during the 50-d dry-AD. The error bars correspond to one-standard deviation.

\subsection{Degradation of substrates and compositional changes}

Compositional analyses of the wheat straw and wool textile waste were performed, before and after the 50-day long digestion period at the TS contents of $13 \%$ and $21 \%$. When investigating the straw samples, changes 
in the composition (cellulose, hemicellulose, and extractives) were defined by measuring the corresponding mass reductions between the beginning and end of the 50-day digestion (Fig. 2) The compositional analysis of the un-treated wheat straw showed $35.2 \%$ cellulose and $22.2 \%$ hemicellulose content (Fig. $2 \mathrm{~A}$ and $2 \mathrm{~B}$ ). The cellulose content of the straw residues obtained after the dry-AD digestion at the $13 \%$ TS with and without the addition of enzymes were $10.0 \%$ and $11.2 \%$, respectively. The highest levels of cellulose degradation of 69 and $71 \%$ were observed when cellulolytic enzymes were added to the digestion process using the TS contents of 13 and $21 \%$, respectively. A similar trend was observed in the hemicellulose removal as well, showing a reduction in hemicelluloses by 69 and $66 \%$, when the digestion process was performed at the TS contents of 13 and $21 \%$, respectively, both with the addition of enzymes. On the other hand, the hemicellulose reduction rate achieved through the dry digestion of the straw, without the addition of enzymes was lower, i.e., 63 and 54\% at the TS contents of 13 and $21 \%$, respectively. Hence, the highest cellulose and hemicellulose degradations were achieved after simultaneous enzymatic hydrolysis and dry-digestion. The optimum temperature for the cellulolytic enzymes added is about $38^{\circ} \mathrm{C}$, which is very close to the mesophilic operation temperature of the dry-AD conducted in this study (Tengborg et al., 2001). This temperature supported the activity of the enzymes resulting in a more efficient first step of the digestion, i.e., the hydrolysis step.

The extractives' content of the wheat straw was $16.6 \%$ of the dry weight, and the degraded wheat straw with and without the addition of cellulolytic enzymes showed $14-38 \%$ reduction in extractives (Fig. 2C). Since the extractives include compounds, such as free sugars, oligomers, and organic acids (Chen et al., 2007; Chen et al., 2010), these compounds can be easily degraded and can potentially contribute to biogas production (Tong et al., 1990). The composition of the extractives was not analysed in this study; however, further research on the degradation of extractive compounds and their contributions to the $\mathrm{AD}$ process would be interesting. The lignin content of the wheat straw remained intact before and after digestion, meaning that this fraction was not subjected to degradation during the digestion period applied.

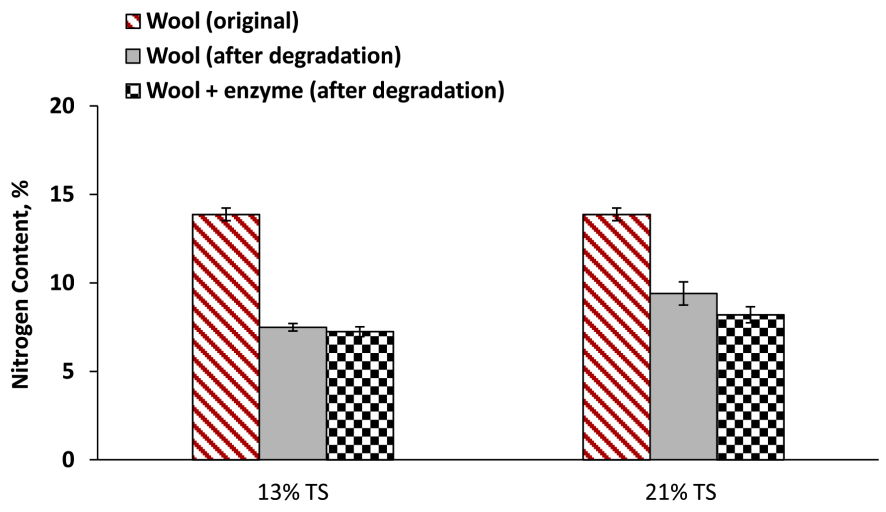

Fig.3. Degradation of nitrogen content $\%$, during the 50-d dry-AD. The error bars correspond to one-standard deviation.

The nitrogen content of the wool textile waste was determined by the Kjeldahl method. The N-content of the wool textiles was $14 \%$, and a reduction of nearly $50 \%$ in the $\mathrm{N}$-content was observed after the digestion, with or without the addition of a protein-degrading enzyme (Fig. 3). The nitrogen content of the wool textile waste after the 50-d degradation period without and with the enzyme addition was 7.5 and $7.24 \%$ in reactors containing $13 \%$ TS, respectively. While the nitrogen content stood at 9.4 and $8.2 \%$ when the $21 \%$ TS without and with the enzyme addition was applied, respectively (Fig. 3). However, these high degradation rates of the wool proteins did not necessarily lead to higher methane productions (Fig. 1). This might be due to the accumulation of ammonium nitrogen as discussed earlier. A lag phase of $20 \mathrm{~d}$ was observed when the wool textile waste was digested at the TS content of 13 and 21\%, and this lag phase was prolonged. Moreover, the conversion of organic matters for gas production did not start up at all when the TS content was increased to $30 \%$. However, the lag phase was shorter, and methane production rate was faster in the more diluted system, i.e., by using the TS content of $6 \%$. The ammonia levels in the digesters at the end of the digestion period were not measured; however, the obtained decrease in the $\mathrm{N}$-content after the digestion on one hand, and the low accumulated methane production determined on the other hand, can indicate an imbalance in the digestion system. It is worth quoting that nitrogen is an important nutrient for microbial growth. However, high concentrations of nitrogen may lead to a severe disturbance in the $\mathrm{AD}$ performance, which can cause a dramatic decrease in microbial activities (Zhang et al., 2011). This in turn results in decreased methane production rates and increased concentrations of intermediate digestion products, like VFAs, which will finally lead to a total termination of methanogenic activity (Sung and Liu, 2003; Calli et al., 2005).

\subsection{Structural changes in wheat straw and wool obtained after dry-AD}

The cellulosic crystallinity of the wheat straw was investigated by FTIR spectrometery. The crystallinity index of the un-treated wheat straw as well as the digested straw obtained after the dry-AD which was performed at the TS concentrations of 13 and $21 \%$ (with and without the addition of enzymes) is shown in Figure 4. The crystallinity index of the un-treated straw was 0.62 ; however, throughout the 50 -d long dry-AD process, the crystallinity index was increased to $1.3-1.5$ when the TS contents of 13 or $21 \%$ were applied, without or with the addition of the cellulolytic enzymes (Fig. 4). As previously mentioned, the crystallinity index is the absorbance ratio between crystalline cellulose $\mathrm{I}$ and the amorphous form of cellulose II $\left(\mathrm{A}_{1422} / \mathrm{A}_{898}\right)$. As shown in Figure 4, there was a significant increase in the crystallinity index after the 50-d digestion period, which was confirmed by the statistical analyses as well $(p=$ 0.000). Since the cellulolytic enzymes can target the less crystalline regions of cellulose fibres (Taherzadeh and Karimi, 2007), this increase in crystallinity indicates that the amorphous cellulose part was initially subjected to biological degradation, subsequently leaving the crystalline cellulose fraction relatively intact.

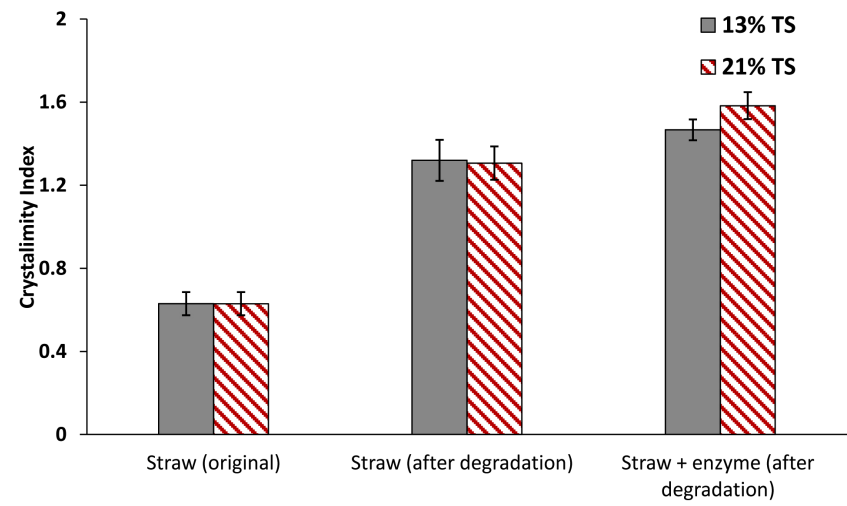

Fig.4. Crystallinity index of wheat straw before and after the 50-d dry-AD. The error bars correspond to one-standard deviation.

The structural changes in the protein microstructure of the wool textile waste were also studied by FTIR (Fig. 5). The amide I (in the range between $1700-1600 \mathrm{~cm}^{-1}$ ) and the amide II (between $1545-1400 \mathrm{~cm}^{-1}$ ) bands, as the most predominant vibrational bands of the protein backbone were investigated (data not shown) (Kong and $\mathrm{Yu}, 2007$ ). These bands are mainly associated with the stretching vibrations of the peptide bonds. The most sensitive spectral region to the protein secondary structure is amide $\mathrm{I}$; therefore, the de-convoluted amide I band was studied in detail to 


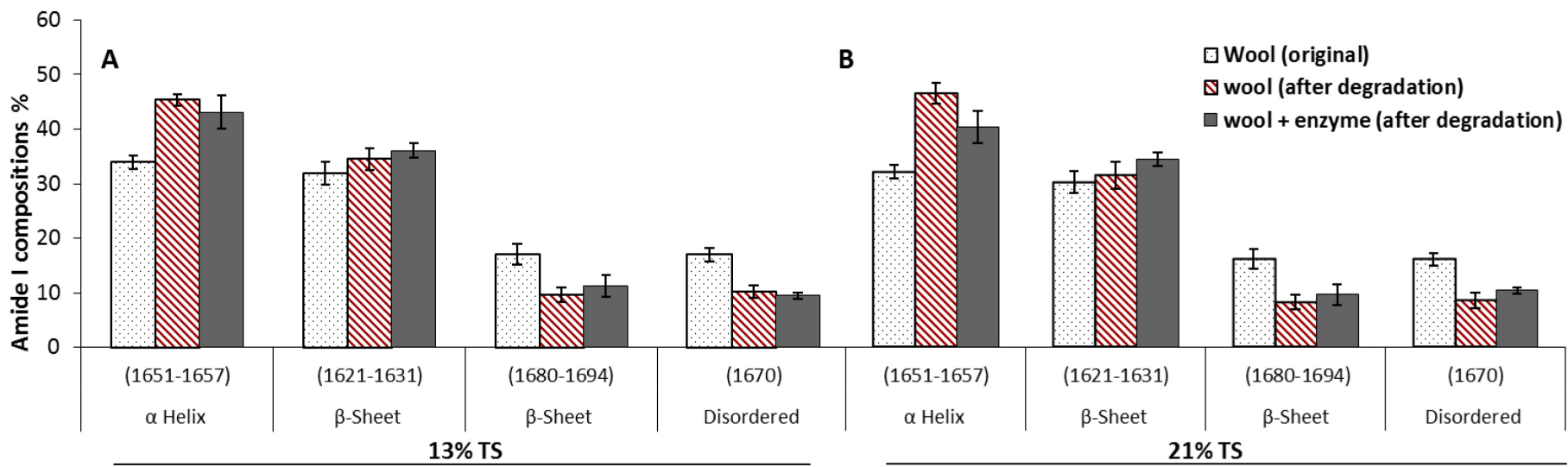

Fig.5. The secondary structure of wool textile protein ( $\alpha$-helix, $\beta$-sheet, and disordered region), before and after the 50-d dry-AD. The error bars correspond to one-standard deviation

understand the changes in the secondary structure of the wool textile protein due to the digestion. The absorption regions of $1631-1621 \mathrm{~cm}^{-1}$ and $1694-$ $1680 \mathrm{~cm}^{-1}$ show the secondary structures of $\beta$-sheet and the absorption regions of $1657-1651 \mathrm{~cm}^{-1}$, and $1679-1670 \mathrm{~cm}^{-1}$ represent the secondary structures of $\alpha$-helix, and disordered regions, respectively. Originally, the wool textile waste contained $29.3 \% \alpha$-helix, $44.4 \% \beta$-sheet, and $17 \%$ disordered regions. There was a decrease (from $17 \%$ to $10 \%$ ) obtained in these disordered regions after the 50-d long digestion period when the TS contents of 13 or $21 \%$ were applied. Consequently, the degradation of the wool textile waste led to an increase in the $\alpha$-helix conformation by $42.5-49.1 \%$ at both TS conditions, both with and without the addition of the protein-degrading enzyme. Furthermore, there was a slight decrease in the $\beta$-sheet conformation after the 50-d dry-AD (Fig. 5). Therefore, it can be concluded that as expected the disordered regions were the most affected regions during the digestion process. However, there is certainly a knowledge gap in the AD of keratinrich substrates and their structural changes during the degradation process, which should be investigated further in the future.

\section{Conclusion}

Overall, the $\mathrm{AD}$ of the straw and wool textile waste using dry digestion technology was found as a promising option compared with the wet $\mathrm{AD}$ systems due to the higher methane yield and productivity, reduction in reactor volume and thus less energy consumption for heating, and finally more economic maintenance. Nevertheless, the results of this study revealed that the TS content applied must be properly adjusted to avoid overloading the system. Moreover, it was also shown that the problems with overloading due to the high TS content could be solved by the co-digestion of different substrates. More specifically, the co-digestion of a carbon-rich substrate (wheat straw) and a nitrogen-rich substrate (wool textile waste) can lead to higher methane production rates than those calculated based on the methane potentials for the single substrates. Moreover, due to the synergetic effects and a better nutritional balance, the TS could be increased to $30 \%$ during the co-digestion without causing serious problems to the digestion system. These findings can open up a new path for cost-effective utilisation of complex biomass-oriented substrates by further optimisation of their co-digestion through dry-AD systems.

\section{References}

[1] Akia, M., Yazdani, F., Motaee, E., Han, D., Arandiyan, H., 2014. A review on conversion of biomass to biofuel by nanocatalysts. Biofuel Res. J. 1(1), 16-25.

[2] Alvarez, R., Lidén, G., 2008. Semi-continuous co-digestion of solid slaughterhouse waste, manure, and fruit and vegetable waste. Renew. Energy. 33(4), 726-734.
[3] Andersson, J., Björnsson, L., 2002. Evaluation of straw as a biofilm carrier in the methanogenic stage of two-stage anaerobic digestion of crop residues. Bioresour. Technol. 85(1), 51-56.

[4] Barchyn, D., Cenkowski, S., 2014. Process analysis of superheated steam pre-treatment of wheat straw and its relative effect on ethanol selling price. Biofuel Res. J. 1(4), 123-128.

[5] Batstone, D.J., Keller, J., Angelidaki, I., Kalyuzhnyi, S.V., Pavlostathis, S.G., Rozzi, A., Sanders, W.T.M., Siegrist, H., Vavilin, V.A., 2002. The IWA Anaerobic Digestion Model No 1 (ADM 1). Water Sci. Technol. 45(10), 65-73.

[6] Bollon, J., Benbelkacem, H., Gourdon, R., Buffière, P., 2013 Measurement of diffusion coefficients in dry anaerobic digestion media. Chem. Eng. Sci. 89, 115-119.

[7] Calli, B., Mertoglu, B., Inanc, B., Yenigun, O., 2005. Effects of high free ammonia concentrations on the performances of anaerobic bioreactors. Process Biochem. 40(3), 1285-1292.

[8] Cardamone, J.M., 2010. Investigating the microstructure of keratin extracted from wool: Peptide sequence (MALDI-TOF/TOF) and protein conformation (FTIR). J. Mol. Struct. 969(1), 97-105.

[9] Carrillo, F., Colom, X., Sunol, J.J., Saurina, J., 2004. Structural FTIR analysis and thermal characterisation of lyocell and viscosetype fibres. Eur. Polym. J. 40(9), 2229-2234.

[10] Chanakya, H.N., Borgaonkar, S., Meena, G., Jagadish, K.S., 1993. Solid phase fermentation of untreated leaf biomass to biogas. Biomass Bioenergy. 5(5), 369-377.

[11] Chandler, J.A., Jewell, W.J., 1980. Predicting methane fermentation biodegradability. Solar Energy Res. Inst. Golden, Colorado.

[12] Chen, S.F., Mowery, R.A., Scarlata, C.J., Chambliss, C.K., 2007 Compositional analysis of water-soluble materials in corn stover. J. Agric. Food. Chem. 55(15), 5912-5918.

[13] Chen, S.F., Mowery, R.A., Sevcik, R.S., Scarlata, C.J., Chambliss, C.K. 2010. Compositional analysis of water-soluble materials in switchgrass. J. Agric. Food. Chem. 58(6), 3251-3258.

[14] De Baere, L., Mattheeuws, B., 2008. State-of-the-art 2008anaerobic digestion of solid waste. Waste management world. 9 (5), $1-8$.

[15] Forgács, G., Lundin, M., Taherzadeh, M., Sárvári Horváth, I., 2013. Pretreatment of chicken feather waste for improved biogas production. Appl. Biochem. Biotechnol. 169(7), 2016-2028.

[16] Ghosh, S., Henry, M., Sajjad, A., Mensinger, M., Arora, J., 2000. Pilot-scale gasification of municipal solid wastes by high-rate and two-phase anaerobic digestion (TPAD). Water Sci. Technol. 41(3), $101-110$

[17] Heine E, Höcker H., 1995. Enzyme treatments for wool and cotton. Rev. Prog. Color. Relat. Top. 25(1), 57-70.

[18] International Wool Textile Organization (IWTO), 2015. Wool The Natural Fiber, IWTO. 
[19] Jewell, W.J., Cummings, R.J., Richards, B.K., 1993. Methane fermentation of energy crops: maximum conversion kinetics and in situ biogas purification. Biomass Bioenergy. 5(3), 261-278.

[20] Jurado, E., Gavala, H.N., Skiadas, I.V., 2013. Enhancement of methane yield from wheat straw, miscanthus and willow using aqueous ammonia soaking. Environ. Technol. 34(13-14), 2069-2075.

[21] Kabir, M.M., Forgács, G., Sárvári Horváth, I., 2013. Enhanced methane production from wool textile residues by thermal and enzymatic pretreatment. Process Biochem. 48(4), 575-580.

[22] Karimi, K., Shafiei, M., Kumar, R., 2013. Progress in physical and chemical pretreatment of lignocellulosic biomass. in: Biofuel Technologies, Springer. pp. 53-96.

[23] Kayhanian, M., Rich, D., 1995. Pilot-scale high solids thermophilic digestion of municipal solid waste with an emphasis on nutrient requirements. Biomass Bioenergy. 8(6-8), 433-444.

[24] Kazda, M., Zak, M., Bengelsdorf, F.R., 2012. Effects of additional biofilms carrierson anaerobic digestion of food wates: results from laboratory experiments and a full-scale application. Anaerobic Digestion of Solid Biomass and Biowaste, Berlin.

[25] Kiran, E.U., Trzcinski, A.P., Liu, Y., 2014. Glucoamylase production from food waste by solid state fermentation and its evaluation in the hydrolysis of domestic food waste. Biofuel Res. J. 1(3), 98-105.

[26] Kong, J., Yu, S., 2007. Fourier transform infrared spectroscopic analysis of protein secondary structures. Acta Biochim. Biophys. Sin. 39(8), 549559.

[27] Kretschmer, B., Allen, B., Hart, K., 2012. Mobilising Cereal Straw in the EU to feed Advanced biofuel production. Institute for European Environmental Policy.

[28] Liew, L.N., Shi, J., Li, Y., 2012. Methane production from solid-state anaerobic digestion of lignocellulosic biomass. Biomass Bioenergy. 46, $125-132$.

[29] Nordberg, Å., Edström, M., 1997. Co-digestion of ley crop silage, straw and manure. in: The Future of Biogas in Europe. Bio Press, Herning, Denmark

[30] Osuna, M.B., Zandvoort, M.H., Iza, J.M., Lettinga, G., Lens, P.N.L., 2003. Effects of trace element addition on volatile fatty acid conversions in anaerobic granular sludge reactors. Environ. Technol. 24(5), 573587.

[31] Pagés Díaz, J., Pereda Reyes, I., Lundin, M., Sárvári Horváth, I., 2011. Co-digestion of different waste mixtures from agro-industrial activities: Kinetic evaluation and synergetic effects. Bioresour. Technol. 102(23), 10834-10840.
[32] Pothiraj, C., Arun, A., Eyini, M., 2015. Simultaneous saccharification and fermentation of cassava waste for ethanol production. Biofuel Res. J. 2(1), 196-202.

[33] Salehian, P., Karimi, K., Zilouei, H., Jeihanipour, A., 2013. Improvement of biogas production from pine wood by alkali pretreatment. Fuel. 106(0), 484-489.

[34] Shafiei, M., Karimi, K., Taherzadeh, M.J., 2011. Technoeconomical study of ethanol and biogas from spruce wood by NMMO-pretreatment and rapid fermentation and digestion. Bioresour. Technol. 102(17), 7879-7886.

[35] Sluiter, A., Hames, B., Ruiz, R., Scarlata, C., Sluiter, J., Templeton, D., 2008a. Determination of ash in biomass. NREL/TP-510-42622 NREL Laboratory Analytical Procedure. National Renewable Energy Laboratory.

[36] Sluiter, A., Hames, B., Ruiz, R., Scarlata, C., Sluiter, J., Templeton, D., Crocker, D., 2008b. Determination of structural carbohydrates and lignin in biomass. NREL/TP-510-42618 NREL Laboratory Analytical Procedure. National Renewable Energy Laboratory.

[37] Sluiter, A., Ruiz, R., Scarlata, C., Sluiter, J., Templeton, D., 2005 Determination of extractives in biomass. Laboratory Analytical Procedure (LAP), 1617.

[38] Sung, S., Liu, T., 2003. Ammonia inhibition on thermophilic anaerobic digestion. Chemosphere. 53(1), 43-52.

[39] Taherzadeh, M.J., Karimi, K., 2007. Enzymatic-based hydrolysis processes for Ethanol. BioResources. 2(4), 707-738.

[40] Tengborg, C., Galbe, M., Zacchi, G., 2001. Influence of enzyme loading and physical parameters on the enzymatic hydrolysis of steam-pretreated softwood. Biotechnol. Progr. 17(1), 110-117.

[41] Tong, X., Smith, L.H., McCarty, P.L., 1990. Methane fermentation of selected lignocellulosic materials. Biomass. 21(4), 239-255.

[42] Ward, A.J., Hobbs, P.J., Holliman, P.J., Jones, D.L., 2008 Optimisation of the anaerobic digestion of agricultural resources. Bioresour. Technol. 99(17), 7928-7940.

[43] Wujcik, W.J., Jewell, W.J., 1980. Dry anaerobic fermentation, Biotechnol. Bioeng. Symp.;(United States). Cornell Univ., NY.

[44] Yang, L., Li, Y., 2014. Anaerobic digestion of giant reed for methane production. Bioresour. Technol. 171, 233-239.

[45] Zhang, Y., Cañas, E.M.Z., Zhu, Z., Linville, J.L., Chen, S., He, Q. 2011. Robustness of archaeal populations in anaerobic co-digestion of dairy and poultry wastes. Bioresour. Technol. 102(2), 779-785.

[46] Zhu, J., Wan, C., Li, Y., 2010. Enhanced solid-state anaerobic digestion of corn stover by alkaline pretreatment. Bioresour. Technol. 101(19), 7523-7528. 